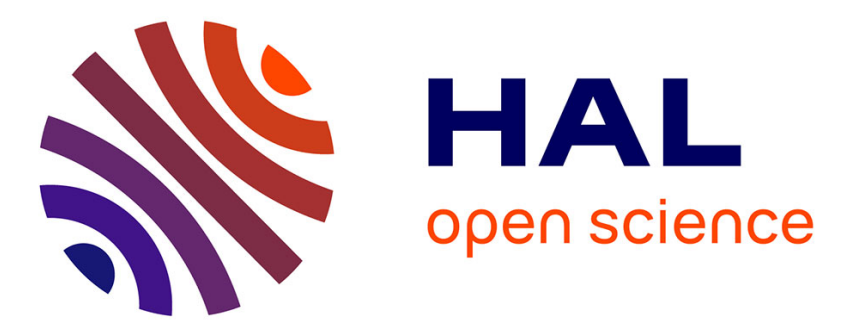

\title{
Analysis of underfloor electrical heating system integrated with coconut oil-PCM plates
}

Khaireldin Faraj, Jalal Faraj, Farouk Hachem, Hassan Bazzi, Mahmoud Khaled, Cathy Castelain

\section{- To cite this version:}

Khaireldin Faraj, Jalal Faraj, Farouk Hachem, Hassan Bazzi, Mahmoud Khaled, et al.. Analysis of underfloor electrical heating system integrated with coconut oil-PCM plates. Applied Thermal Engineering, 2019, 158, pp.113778. 10.1016/j.applthermaleng.2019.113778 . hal-02184821

\section{HAL Id: hal-02184821 \\ https://hal.science/hal-02184821}

Submitted on 26 Nov 2020

HAL is a multi-disciplinary open access archive for the deposit and dissemination of scientific research documents, whether they are published or not. The documents may come from teaching and research institutions in France or abroad, or from public or private research centers.
L'archive ouverte pluridisciplinaire HAL, est destinée au dépôt et à la diffusion de documents scientifiques de niveau recherche, publiés ou non, émanant des établissements d'enseignement et de recherche français ou étrangers, des laboratoires publics ou privés. 


\title{
Analysis of Underfloor Electrical Heating System Integrated with Coconut Oil-PCM Plates
}

\author{
Khaireldin Faraj ${ }^{1}$, Jalal Faraj ${ }^{2}$, Farouk Hachem ${ }^{1}$, Hassan Bazzi², Mahmoud Khaled ${ }^{2,3}$, and Cathy \\ Castelain $^{4}$ \\ ${ }^{1}$ Energy and Thermo-Fluid Group, Lebanese International University LIU, Bekaa, Lebanon \\ ${ }^{2}$ Energy and Thermo-Fluid Group, International University of Beirut BIU, Beirut, Lebanon \\ ${ }^{3}$ University Paris Diderot, Sorbonne Paris Cite, Interdisciplinary Energy Research Institute (PIERI), Paris, France \\ ${ }^{4}$ Heat Transfer and Energy Group, Polytech Nantes, University of Nantes, Nantes, France
}

\begin{abstract}
In the present study, coconut oil was used as a new bio-based phase change material (PCM) to be integrated with a quarter-scale insulated prototype of an underfloor heating system and its performance was investigated. Two different cases were studied. In the first case, the PCM was placed in an aluminum container that was positioned above an electrical heater, and the adaptation of the PCM to the floor was investigated. The second case was a control test in the absence of PCM plates. To simulate real severe winter conditions, the prototype was tested in an agricultural refrigerator to ensure constant low ambient temperature. The versatility of the underfloor system with PCM facilitates a reduction in heating load during winter while maintaining residential thermal comfort. An economic study was then conducted based on contemporary electricity shifts to inspect the system's ability in peak load shifting. The results show that the PCM achieved an increase of $53.7 \%$ in the duration of energy transfer across charging and discharging. Furthermore, the use of the bio-PCM facilitated a shift in electricity consumption from peak time to off-peak time, yielding an annual cost reduction of $58.9 \%$ when compared with that achieved in the control test.
\end{abstract}

Keywords: Phase change material, Energy storage, Latent heat, Coconut Oil, Prototype, Underfloor electrical heating system

\section{Introduction}

The ongoing rapid growth in world population and economies is causing tremendous increases in global energy demand and consumption, thereby playing a significant role in triggering severe environmental impacts [1]-[4]. According to the International Energy Agency, primary energy production and $\mathrm{CO}_{2}$ emissions have increased by $49 \%$ and $43 \%$, respectively, over the past two decades [5]. In the European Union, the building sector is the main consumer of energy, accounting for $40 \%$ of the total energy usage [5]. However, the resultant environmental crisis has only just begun, with the energy demand of the building sector forecast to increase to $50 \%$ of the total by 2050 , and demand for space cooling expected to triple during this period [5]. Hence, researchers are seeking potential solutions to ameliorate energy conservation and energy storage in an attempt to disrupt the advance of global 
warming. One of the prescribed methods is the integration of thermal energy storage (TES) technologies in buildings to help reduce peak loads, uncouple energy demand from its availability, facilitate the integration of renewable energy sources, and provide efficient management of thermal energy, thus improving the energy efficiency of buildings [6]. Latent heat TES technologies using phase change materials (PCMs) have gained extensive attention in building applications due to their high energy storage densities [7]. The coupling of PCM layers with underfloor radiant heating systems is considered one of the most efficient active techniques. Researchers have integrated PCM plates with underfloor electrical heating systems more often than with underfloor hydronic heating systems [8], where, for building applications, PCMs with melting points in the range $18-30^{\circ} \mathrm{C}$ are mostly preferred to meet the requirements of thermal comfort and floor surface temperature [4].

Several researches have been conducted on the performance of PCMs in buildings. Lin et al. [8] conducted an experiment to test the effectiveness of shape-stabilized PCMs (SSPCMs) in an underfloor electric heating system. The results showed that an increase in indoor temperature was achieved but fluctuations in the maximum and minimum temperatures attained during the functioning and stopping of the heaters remained unchanged. Additionally, more than half of the total electricity consumption was shifted from peak hours to off-peak hours, providing economic benefits due to the difference between the daytime and nighttime electricity tariffs in Beijing, China.

In another research, Yinping et al. [9] worked on SSPCMs to determine suitable thermophysical properties. Their experiment included the use of PCMs with melting points of $20{ }^{\circ} \mathrm{C}$ and $60{ }^{\circ} \mathrm{C}$. They concluded that the optimal melting temperature of PCMs used with electric underfloor heating systems is $40{ }^{\circ} \mathrm{C}$, and that the optimal heat of fusion is in the range $120-160 \mathrm{~kJ} / \mathrm{kg}$. They also determined that the PCM thickness must not exceed $2 \mathrm{~cm}$.

Devaux and Farid [10] numerically validated the experimental results obtained from two identical huts built on the Tamaki campus of the University of Auckland, New Zealand; they employed EnergyPlus software to model the rooms installed with PCM-based underfloor heating systems. The results emphasized that a cost saving of $42 \%$ corresponding to an energy saving of $32 \%$ was attained. In a similar study on the same prototypes, Barzin et al. [11] reported a total cost saving of $18.8 \%$ corresponding to an energy saving of $28.7 \%$, with the maximum cost and energy savings attained being $35 \%$ and $44.4 \%$, respectively. The authors highlighted the importance of the proper selection of PCMs in terms of melting temperature to best meet the thermal comfort requirements.

The thermal performances of hot water floor panels with different heating pipes, i.e., polyethylene coils (PE pipes) and capillary mat (CAP mat), incorporated with different TES materials (sand and PCM), were experimentally studied by Zhou and He [12]. The results showed that when compared with PE pipes, CAP mat provided more uniform vertical temperature distribution and higher heat storage rate but required less time to attain a comfortable level of indoor temperature during the process of charging. Furthermore, it was proven that the time of discharge of the PCM storage (latent) was twice that of sand (sensible), which is evidence that PCM is the best choice for load shifting. Cheng et al. [13] discussed the energy savings, economic benefits, and cost-effective performance of high-density polyethylene SSPCMs used in underfloor heating systems, as well as the effect of the thermal conductivities of SSPCMs on their performances. Huang et al. [14] performed a numerical analysis and validated it experimentally for a newly designed solar water heating system utilizing capillary pipes placed above and below a prefabricated concrete skeleton with 169 vacancies in which macro-encapsulated capric acid PCM was placed. Their results showed that the energy storage capacity of the floor is greatly 
enhanced while the need for space for the water tank is eliminated. The authors recommend PCM thicknesses of $60 \mathrm{~mm}$ and $40 \mathrm{~mm}$ for use in cities with higher and lower heating loads, respectively. A review of the studies in the literature is presented in Table 2.

Table 1 Studies in the literature on underfloor radiant heating with PCM

\begin{tabular}{|c|c|c|c|c|c|}
\hline Author & Year & $\begin{array}{l}\text { PCM floor layer } \\
\text { properties }\end{array}$ & $\begin{array}{l}\text { PCM } \\
\text { integration } \\
\text { method }\end{array}$ & $\begin{array}{l}\text { Heating } \\
\text { method }\end{array}$ & Results \\
\hline Lin et al. [8] & 2005 & $\begin{array}{c}\text { Paraffin-based } \\
\left(\mathrm{T}_{\mathrm{m}}=52^{\circ} \mathrm{C} \text { and }\right. \\
\mathrm{H}=150 \mathrm{~kJ} / \mathrm{kg})\end{array}$ & $\begin{array}{l}\text { Shape- } \\
\text { stabilized* }\end{array}$ & Electrical & $\begin{array}{l}\text { Indoor temperature increased, and more } \\
\text { than half of the total electric energy } \\
\text { consumption was shifted from peak } \\
\text { position to off-peak position. }\end{array}$ \\
\hline Yinping et al. [9] & 2006 & $\begin{array}{c}\text { Paraffin-based } \\
\left(\mathrm{T}_{\mathrm{m}}=20^{\circ} \mathrm{C} \text { or } 60^{\circ} \mathrm{C}\right. \\
\text { and } \mathrm{H}=62-138 \\
\mathrm{~kJ} / \mathrm{kg})\end{array}$ & $\begin{array}{l}\text { Shape- } \\
\text { stabilized* }\end{array}$ & Electrical & $\begin{array}{l}\text { Optimum SSPCM layer has a melting } \\
\text { temperature of } 40{ }^{\circ} \mathrm{C} \text { and maximum } \\
\text { thickness of } 2 \mathrm{~cm} .\end{array}$ \\
\hline Ansuini et al. [15] & 2011 & $\begin{array}{l}\text { Paraffin-based } \\
\left(\mathrm{T}_{\mathrm{m}}=27^{\circ} \mathrm{C} \text { and }\right. \\
\mathrm{H}=72 \mathrm{~kJ} / \mathrm{kg})\end{array}$ & $\begin{array}{c}\text { Macro- } \\
\text { encapsulated }\end{array}$ & $\begin{array}{l}\text { Hot } / \text { cold } \\
\text { water }\end{array}$ & $\begin{array}{l}\text { PCM floor was efficient for radiant } \\
\text { cooling (saving of } 25 \% \text { of the water used } \\
\text { for cooling) in summer, and did not affect } \\
\text { the heating behavior of the plant in winter. }\end{array}$ \\
\hline Royon et al. [16] & 2013 & $\begin{array}{c}\text { Paraffin-based } \\
\left(\mathrm{T}_{\mathrm{m}}=27^{\circ} \mathrm{C} \text { and }\right. \\
\mathrm{H}=110 \mathrm{~kJ} / \mathrm{kg})\end{array}$ & $\begin{array}{l}\text { Shape- } \\
\text { stabilized* }\end{array}$ & Hot water & $\begin{array}{l}\text { Storage of solar energy, thereby avoiding } \\
\text { large increase in indoor temperature } \\
\text { during the day and facilitating energy } \\
\text { release at night }\end{array}$ \\
\hline Karim et al. [17] & 2014 & $\begin{array}{l}\text { Paraffin-based } \\
\left(\mathrm{T}_{\mathrm{m}}=27^{\circ} \mathrm{C} \text { and }\right. \\
\mathrm{H}=110 \mathrm{~kJ} / \mathrm{kg})\end{array}$ & $\begin{array}{l}\text { Shape- } \\
\text { stabilized* }\end{array}$ & Hot water & $\begin{array}{l}\text { Increase in thermal energy storage } \\
\text { capability and peak shifting }\end{array}$ \\
\hline Huang et al. [14] & 2014 & $\begin{array}{c}\text { Capric acid } \\
\left(\mathrm{T}_{\mathrm{m}}=29.2^{\circ} \mathrm{C} \text { and }\right. \\
\mathrm{H}=162 \mathrm{~kJ} / \mathrm{kg})\end{array}$ & $\begin{array}{c}\text { Macro- } \\
\text { encapsulated }\end{array}$ & Solar water & $\begin{array}{l}\text { PCM floor releases } 47.7 \% \text { of the energy } \\
\text { supplied by solar water. }\end{array}$ \\
\hline Zhou and He [12] & 2015 & $\begin{array}{l}\text { Inorganic } \mathrm{PCM} \\
\left(\mathrm{T}_{\mathrm{m}}=29^{\circ} \mathrm{C} \text { and }\right. \\
\mathrm{H}=220 \mathrm{~kJ} / \mathrm{kg})\end{array}$ & $\begin{array}{c}\text { Macro- } \\
\text { encapsulated }\end{array}$ & Hot water & $\begin{array}{l}\text { PCM (latent) attained twice as much } \\
\text { discharging time as sand (sensible) to } \\
\text { ensure thermal comfort. }\end{array}$ \\
\hline Barzin et al. [11] & 2015 & $\begin{array}{c}\text { Paraffin-based } \\
\left(\mathrm{T}_{\mathrm{m}}=28^{\circ} \mathrm{C} \text { and }\right. \\
\mathrm{H}=120 \mathrm{~kJ} / \mathrm{kg})\end{array}$ & Impregnation & Electrical & $\begin{array}{l}\text { - Cost saving of } 18.8 \% \text { over } 5 \text { days ( } 35 \% \\
\text { maximum) } \\
\text { - Energy saving of } 28.7 \% \text { over } 5 \text { days } \\
\text { (44.4\% maximum) }\end{array}$ \\
\hline Cheng et al. [13] & 2015 & $\begin{array}{l}\text { Paraffin-based } \\
\left(\mathrm{T}_{\mathrm{m}}=30.3^{\circ} \mathrm{C} \text { and }\right. \\
\mathrm{H}=80.85 \mathrm{~kJ} / \mathrm{kg})\end{array}$ & $\begin{array}{l}\text { Shape- } \\
\text { stabilized* }\end{array}$ & Electrical & $\begin{array}{l}\text { PCM system had the lowest electricity } \\
\text { consumption compared with other heating } \\
\text { systems. }\end{array}$ \\
\hline $\begin{array}{l}\text { Thieblemont et al. } \\
\qquad[18]\end{array}$ & 2016 & Sensible & - & Electrical & $\begin{array}{l}84 \% \text { of building loads are shifted to the } \\
\text { nighttime while maintaining acceptable } \\
\text { thermal comfort in cold climate. }\end{array}$ \\
\hline Zhou et al. [19] & 2016 & $\begin{array}{c}\text { Paraffin-based } \\
\left(\mathrm{T}_{\mathrm{m}}=24-29^{\circ} \mathrm{C} \text { and }\right. \\
\mathrm{H}=170 \mathrm{~kJ} / \mathrm{kg})\end{array}$ & $\begin{array}{l}\text { Shape- } \\
\text { stabilized* }\end{array}$ & $\begin{array}{l}\text { Hot } / \text { cold } \\
\text { water }\end{array}$ & $\begin{array}{l}\text { Maximum saving of } 16.2 \% \text { in annual } \\
\text { heating energy consumption, and a } \\
\text { reduction of } 41.3 \% \text { in indoor air relative } \\
\text { temperature fluctuation rate for heating } \\
\text { were achieved. }\end{array}$ \\
\hline $\begin{array}{c}\text { Devaux and Farid } \\
{[10]}\end{array}$ & 2017 & $\begin{array}{c}\text { Paraffin-based } \\
\left(\mathrm{T}_{\mathrm{m}}=28^{\circ} \mathrm{C} \text { and }\right. \\
\mathrm{H}=120 \mathrm{~kJ} / \mathrm{kg})\end{array}$ & Impregnation & Electrical & $\begin{array}{l}\text { Cost saving of } 42 \% \text { corresponding to an } \\
\text { energy saving of } 32 \% \text { was achieved. }\end{array}$ \\
\hline Lu et al. [20] & 2018 & $\begin{array}{c}\text { Paraffin-based } \\
\left(\mathrm{T}_{\mathrm{m}}=36^{\circ} \mathrm{C} \text { and }\right. \\
\mathrm{H}=73.6-79.3 \mathrm{~kJ} / \mathrm{kg})\end{array}$ & $\begin{array}{c}\text { Macro- } \\
\text { encapsulated }\end{array}$ & $\begin{array}{c}\text { Hot water } \\
\text { with sunspace }\end{array}$ & $\begin{array}{l}\text { In the passive energy storage stage, the } \\
\text { average indoor temperature of the } \\
\text { experimental room was } 7.15{ }^{\circ} \mathrm{C} \text { higher } \\
\text { than that in conventional storage, whereas } \\
\text { an average energy saving rate of } 54.27 \%\end{array}$ \\
\hline
\end{tabular}


was achieved by the PCM room in the active control stage.

\begin{tabular}{|c|c|c|c|c|c|}
\hline Plytaria et al. [21] & 2018 & $\begin{array}{c}\text { Bio-based Q29-M91 } \\
\left(\mathrm{T}_{\mathrm{m}}=29^{\circ} \mathrm{C} \text { and }\right. \\
\mathrm{H}=180 \mathrm{~kJ} / \mathrm{kg})\end{array}$ & $\begin{array}{c}\text { Macro- } \\
\text { encapsulated }\end{array}$ & $\begin{array}{l}\text { Solar-assisted } \\
\text { heat pump }\end{array}$ & $\begin{array}{l}\text { A } 40 \% \text { reduction in heating load was } \\
\text { achieved using PCM in the floor, and a } \\
\text { reduction of } 42-67 \% \text { in electricity } \\
\text { consumption was obtained in solar-driven } \\
\text { systems. }\end{array}$ \\
\hline
\end{tabular}

The above review of the literature reveals that most published works have focused on the use of commercial PCM that is mainly organic with the objectives of realizing energy savings and desirable thermal behaviors. A few researchers have included economic studies in their works. Some researches were based only on simulations and others focused on experimental results, which merit further investigation. Therefore, the present work presents macro-encapsulation using containers to yield cheap bio-based PCMs with suitable thermophysical, economic, and environmental properties for use in underfloor electrical heating systems, with a transition temperature range close to the optimal temperature required to ensure human comfort. The purposes of this work are to: (1) introduce and offer a comparative experimental study of an underfloor electric heating system integrated with coconut oilPCM (CO-PCM) plates with a melting point of $28^{\circ} \mathrm{C}$; (2) experimentally investigate its thermal performance and feasibility of practical application; (3) offer experimental data to model and simulate such a system; and (4) offer an economic study that is applicable to residents of Lebanon.

\section{Theoretical Background}

The investigation of the performance of CO-PCM plates led to experimental results of temperature as a function of time, and the thermal comfort temperature is the limit at which the process of heating stops. At that stage, the energy consumed can be calculated using the following relation.

$$
E=P \times \Delta t
$$

where $\mathrm{E}$ is the energy consumed $(\mathrm{kWh}), \mathrm{P}$ is the power consumed $(\mathrm{kW})$ and is equal to the voltage $(\mathrm{V})$ multiplied by the current (A), and $\Delta \mathrm{t}$ is the duration of the process of heating when the heater is on (h).

Furthermore, the operational cost is evaluated using the following equation.

$$
\text { O.C. }=E \times E r
$$

where O.C. is the operational cost (in USD or LBP), and $\mathrm{Er}$ is the electricity rate (USD/kWh) or (LBP/kWh).

\section{Materials and Methods}

In the current work, the effect of using CO-PCM with an underfloor heating system on the thermal comfort temperature and energy consumption reduction in a quarter-scale test prototype is investigated. The set-up of the prototype, instrumentation used, and measurement methodology are presented in the following sections. 


\subsection{Prototype set-up}

The prototype is composed of four walls, a floor, and a roof. One wall contains a small glass door, and on the wall to its right is a small window. A schematic diagram showing the appearance of the test room and a photographic image of its realistic appearance are presented in Figure 1.

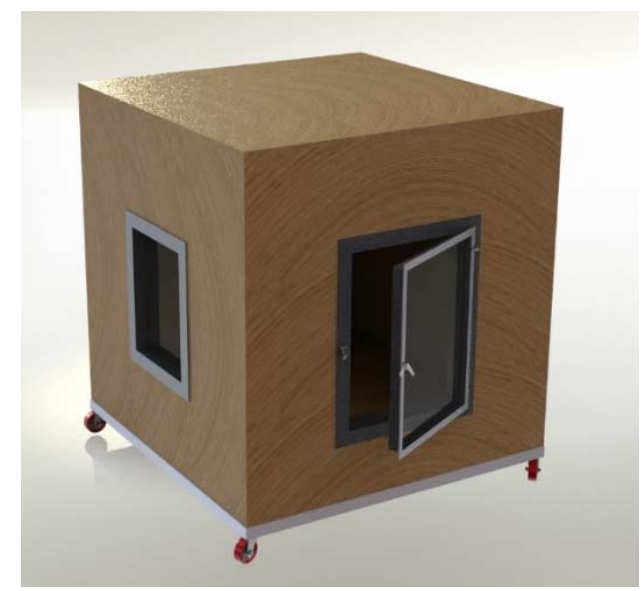

(a)

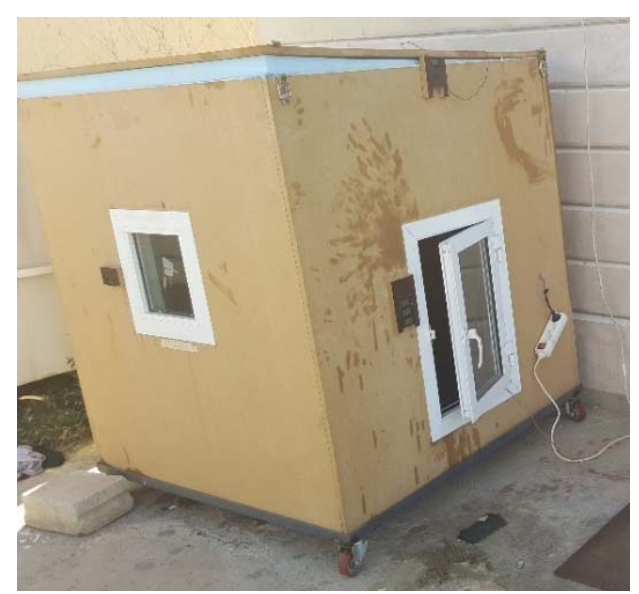

(b)

Figure 1 (a) 3D schematic drawing of the prototype, and (b) photo of the real prototype

The prototype proposed is assembled such that its walls and roof have the same structural design whereas a more complicated design is prescribed for the floor as it contains the source of energy in the system.

\subsubsection{Wall and roof designs}

The walls and roof are designed such that each section comprises 3 layers. There is a set of double medium density fiberboard (MDF) wooden layers with relatively low thermal conductivity $\left(\lambda_{\text {wood }}=0.3\right.$ $\mathrm{W} / \mathrm{m} . \mathrm{K}$ ) and thickness of $17.65 \mathrm{~mm}$. Between these layers lies a thick layer of extruded polystyrene foam (XPS) used as insulation material with thickness of $50 \mathrm{~mm}$, thermal conductivity ( $\lambda$ XPs) of 0.033 $\mathrm{W} / \mathrm{m} . \mathrm{K}$, specific heat of $1.5 \mathrm{~kJ} / \mathrm{kg} . \mathrm{K}$, and density of $35 \mathrm{~kg} / \mathrm{m}^{3}$.

\subsubsection{Underfloor design}

For the square floor with sides of $118 \mathrm{~cm}$, previous researchers [8] have proposed that the floor sections comprise five main layers from the bottom to the top as follows: base layer, insulation layer, the heating system, PCM containers bearing PCM with an air gap above, and finally the floor surface layer. The basic dimensions of the room with a cross-section showing the floor assembly as per the prescribed design are illustrated in Figure 2. 


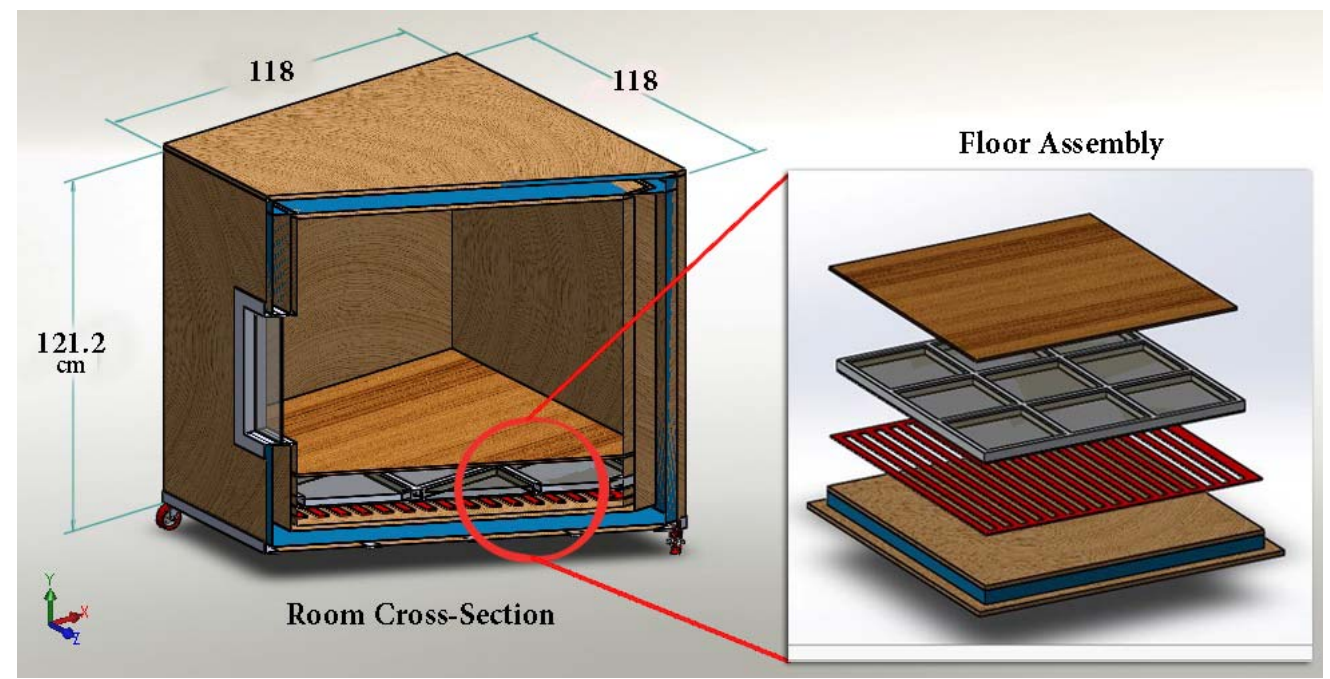

Figure 2 Schematic diagram obtained from SolidWorks showing the cross-section of the prototype tested and the floor assembly

The base layer is made of MDF wood ( $\left.\lambda_{\text {wood }}=0.3 \mathrm{~W} / \mathrm{m} . \mathrm{K}\right)$ and has a thickness of $17.65 \mathrm{~mm}$. The insulation layer is composed of materials with low thermal conductivities to minimize downward energy loss. For the design of the insulation layer, Lin et al. recommended the use of polystyrene $(\lambda=0.03$ $\mathrm{W} / \mathrm{m} . \mathrm{K})$ with a thickness of $120 \mathrm{~mm}$ [8]. However, Zhou et al. used expanded polystyrene sheets $(\lambda=$ $0.035 \mathrm{~W} / \mathrm{m} . \mathrm{K}), 10 \mathrm{~mm}$ thick [19]. The current study adopts the design of Lin et al. with modifications to the thickness; the XPS layer is $50 \mathrm{~mm}$ thick due to the difference in the scale of the room tested and the resultant size limitations. Another MDF layer, $17.65 \mathrm{~mm}$ thick, is bound to the insulation with the heater lying on the wooden layer. The heating system is composed of an underfloor electric heating mat with specifications as listed in Table 2.

Table 2 Specifications of the underfloor electric heating system used in the prototype.

\begin{tabular}{c|c}
\hline PMAT specification & Value \\
\hline \hline Rated power & $200 \mathrm{~W}$ \\
Voltage & $220 \mathrm{~V}$ \\
Current & $1.8 \mathrm{~A}$ \\
Resistance & $251-290 \Omega$ \\
\hline
\end{tabular}

Above the heating system lies an aluminum plate with 9 cavities to hold the PCM (see Figure 3). Yinping et al. recommended that the PCM should have a minimum thermal conductivity of $0.5 \mathrm{~W} / \mathrm{m} . \mathrm{K}$, minimum heat of fusion of $120 \mathrm{~kJ} / \mathrm{kg}$, and maximum thickness of $20 \mathrm{~mm}$ [9]. For emphasis, Lin et al. included in their design a PCM with thickness of $15 \mathrm{~mm}$ [8]. However, in the current study, coconut oil is employed as the PCM, with a thickness of $25 \mathrm{~mm}$ and thermophysical properties as given in Table 3. The latent heat for CO-PCM was measured to be $254.5 \mathrm{~kJ} / \mathrm{kg}$ using the T-history method wherein the reference values of $249 \mathrm{~kJ} / \mathrm{kg}$ and $198 \mathrm{~kJ} / \mathrm{kg}$ are obtained from a previous study on the thermophysical characterization of coconut oil [22]. An air gap, $10 \mathrm{~mm}$ thick, was left above the PCM $\left(\lambda_{\text {air }}=0.0263\right.$ $\mathrm{W} / \mathrm{m} . \mathrm{K}$ at $27^{\circ} \mathrm{C}$ [23]) to prevent any spillage during phase change. Finally, a $10 \mathrm{~mm}$ thick wooden board covered the plate. Figure 3 shows the design of the floor with its dimensions. 
Table 3 Thermophysical properties of CO-PCM used in the study

\begin{tabular}{c|c|c}
\hline PCM specification & TQP experimental tests & Reference \\
Name & \multicolumn{2}{|c}{ Coconut Oil } \\
Type & \multicolumn{2}{|c}{ Bio-PCM } \\
$\begin{array}{c}\text { Heat of fusion } \mathrm{H}_{\mathrm{f}}(\mathrm{kJ} / \mathrm{kg}) \\
\text { Melting temperature } \mathrm{T}_{\mathrm{m}}\left({ }^{\circ} \mathrm{C}\right)\end{array}$ & 254.5 & $249[22], 198[22], 70-100[24]$ \\
Specific heat $\mathrm{Cp}(\mathrm{kJ} / \mathrm{kg} . \mathrm{K})$ & 28 & $25[22], 26[24]$ \\
Thermal conductivity $\lambda(\mathrm{W} / \mathrm{m} . \mathrm{K})$ & 2.1 & $2.1[22], 3.23$ (solid) and 2.35 (liquid) \\
Density $\rho\left(\mathrm{kg} / \mathrm{m}^{3}\right)$ & - & {$[24], 3.5[25]$} \\
Firing alerts & - & $0.5[25]$
\end{tabular}

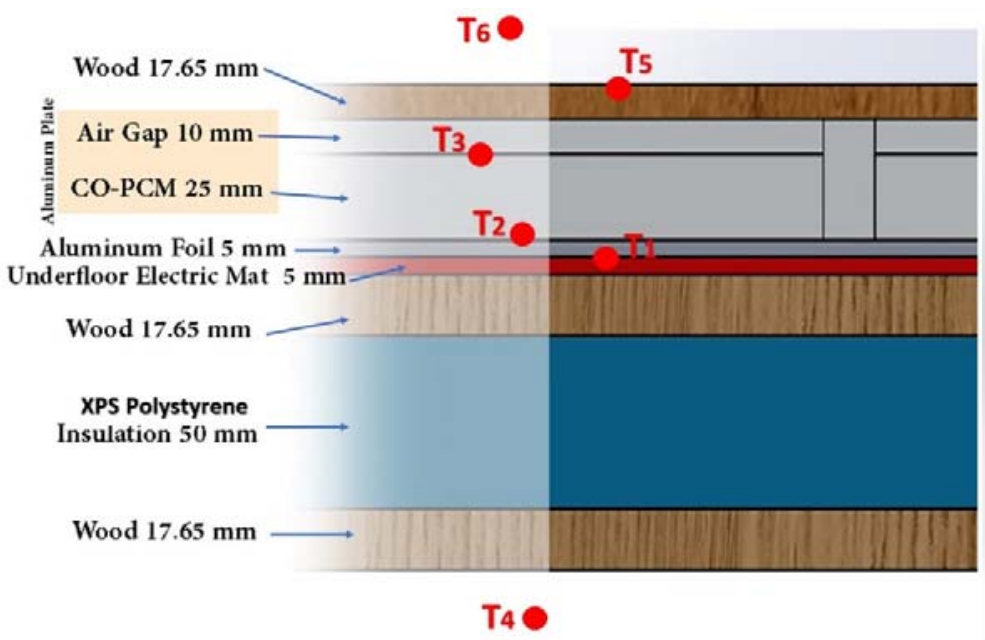

(a)

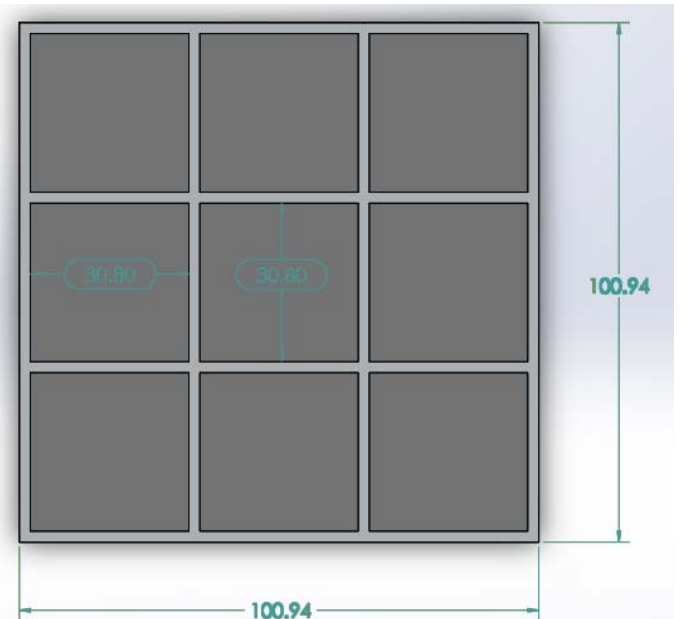

(b)

Figure 3 (a) Cross-section of the floor showing the dimensions of its different sections, and (b) the dimensions of the top view of the PCM plate.

\subsection{Instrumentation}

To test the performance of coconut oil, thermocouples of type $\mathrm{K}$ were used in separate positions, as illustrated in Figure 3. The thermocouples were connected to a data logger, which was equipped with a P.A. Hilton Data Loggers program (HDL software) operated by a desktop computer. The prototype was tested in a large agricultural refrigerator in Izz Al Arab village, Bekaa District, Lebanon. A simulated cold weather (temperature in the range $0-5{ }^{\circ} \mathrm{C}$ ) was maintained during the period of testing.

Since the analysis in the study is based on the temperatures measured, the uncertainty analysis is based only on temperature. Variations in heater temperature in the prototype are considered in the case of tests repeated twice under identical operating conditions and configurations. It was found that the mean temperature difference between the tests is about $0.547{ }^{\circ} \mathrm{C}$, i.e., $1.123 \%$ in relative terms, suggesting that the temperature variation is well reproduced by repeating the test and conserving the same operating conditions. These behaviors were also observed indoors and on floor surfaces with the relative differences remaining lower than $1.5 \%$. With a minimum temperature of $40{ }^{\circ} \mathrm{C}$, the maximum relative error due to the present method of thermocouple fixation does not exceed $0.5 \%$. 
Finally, with a repeatability of $1.5 \%$ and precision error of temperature measurement of $0.5 \%$, the uncertainty is $\left((1.5)^{2}+(0.5)^{2}\right)^{0.5}=1.5 \%$, resulting in $98.5 \%$ confidence in temperature measurements.

\subsection{Measurement Methodology}

The prescribed scenarios and conditions are subdivided into two tests: (a) the control test with no PCM involved, and (b) the test involving the integration of the CO-PCM plates in the floor. Both tests were conducted under the same conditions of ambient temperature, heating power, testing time, and prototype design involved.

According to the measurement protocol followed, each test is started by running the data logging software and the heater simultaneously once the ambient temperature has stabilized below $5{ }^{\circ} \mathrm{C}$. The thermocouples record data into the software and this data is saved in Excel files. In both the tests, the heater is switched off once the temperature inside the test room reaches the optimum design condition in cold weather $\left(22^{\circ} \mathrm{C}\right)$, as proposed by the American Society of Heating, Refrigeration and AirConditioning Engineers [27]. Data continues to be recorded until the room temperature returns to its initial value. The duration of each test is summarized in Figure 4.

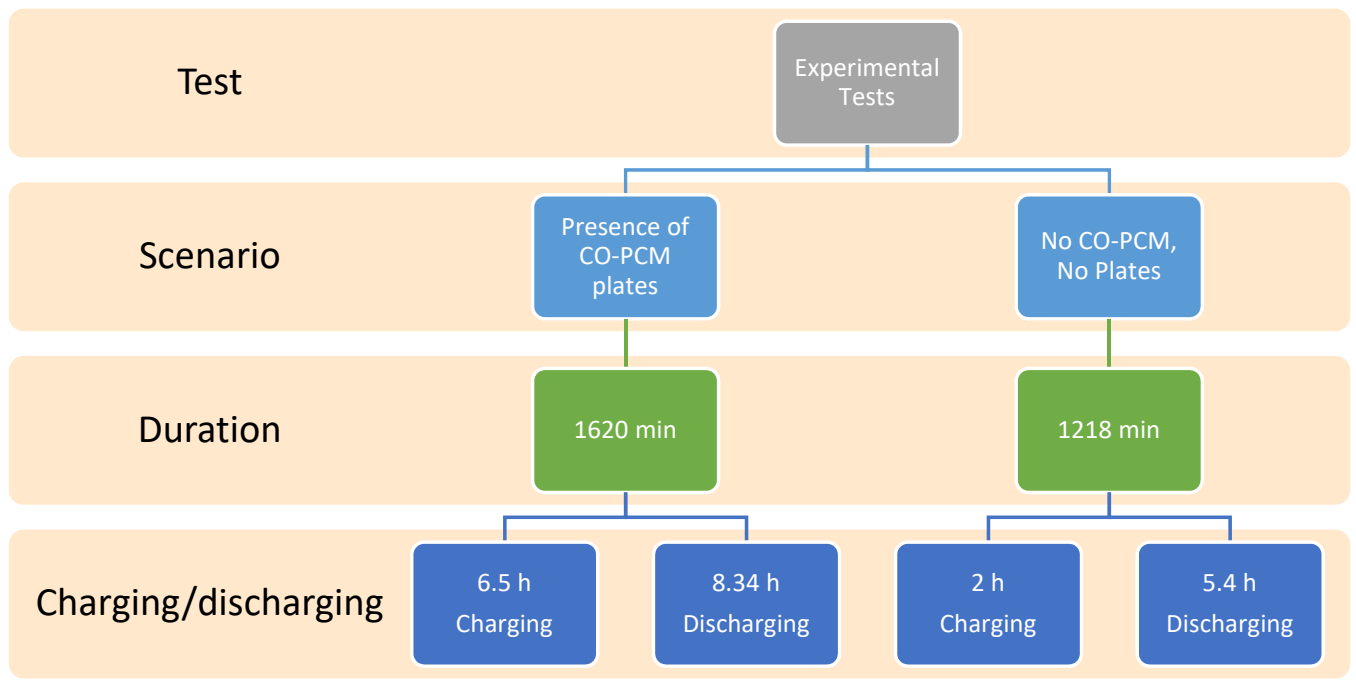

Figure 4 Test scenarios and their respective specifications and durations

\section{Results and Analysis}

The basic function of the PCM is to store latent heat energy while the room is being heated and discharge the stored energy when the heater is off or the electricity rate becomes high, i.e., during peak hours in developed nations and as the case may be in developing nations. Figure 5 shows the variations in the different temperatures as functions of time during the control test in which no PCM is integrated in the prototype. 


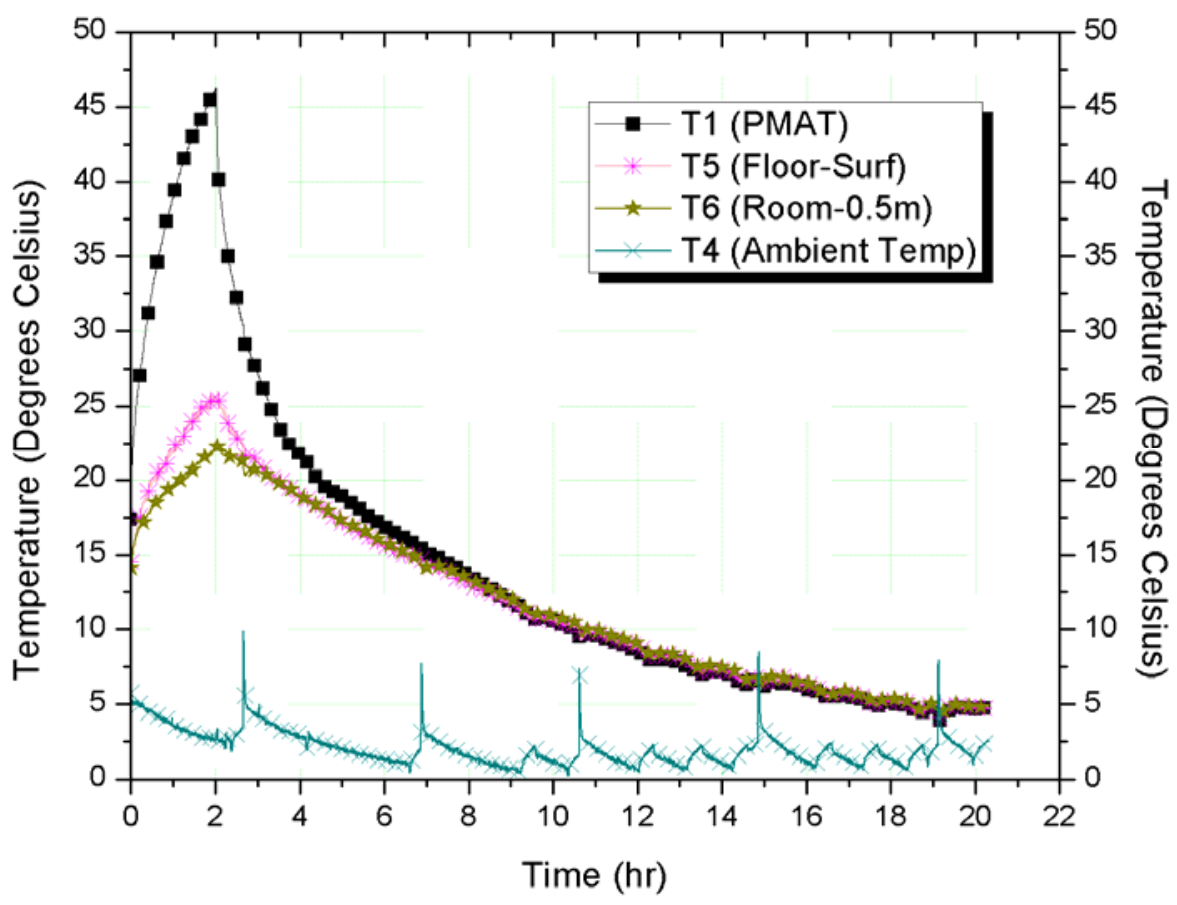

Figure 5 Variation in temperature with respect to time in the control test.

As shown in the figure, the duration of heating the room from $15^{\circ} \mathrm{C}$ to the comfort temperature of $22{ }^{\circ} \mathrm{C}$ was $2 \mathrm{~h}$, and thereafter the room temperature decreased and the temperature of the PMAT returned to its initial value in $5.4 \mathrm{~h}$. The remarkably rapid decrease in the PMAT temperature after it is switched off $\left(31.26^{\circ} \mathrm{C}\right.$ over $\left.5.4 \mathrm{~h}\right)$ is evident. The ambient temperature $\mathrm{T} 4$ appeared to fluctuate in the range 0 $10{ }^{\circ} \mathrm{C}$ with an average value of less than $5{ }^{\circ} \mathrm{C}$. This fluctuation is due to the thermostatic effect of the agricultural refrigerator containing the test room.

The next step was the integration of the PCM with the floor to investigate its performance. Scenario 2 was implemented through the addition of the plates containing CO-PCM. As depicted in Figure 5, the duration of heating the room from $15{ }^{\circ} \mathrm{C}$ to $22{ }^{\circ} \mathrm{C}$ was $6.5 \mathrm{~h}$, which is much higher than in the control test. This is due to the lack of thermal contact between the PCM and the floor surface due to the presence of the low-thermal conductivity air gap or the fusion of oil, and hence a new method of transferring coconut oil into a SSPCM would contribute to the alleviation of such a problem. On the other hand, the time taken for the room temperature to decrease from $22{ }^{\circ} \mathrm{C}$ to $15{ }^{\circ} \mathrm{C}$ in the presence of the PCM was 8.34 hours, which reflects an increase of $53.7 \%$ in duration when compared with the control test. It is also observed from Figure 6 that the room temperature remained approximately constant at the comfort temperature for more than $75 \mathrm{~min}$ after the heater was switched off before starting to decrease and eventually return to its initial value. Thus, the delay ensured the effectiveness of the CO-PCM even before the onset of the latent heating stage.

For a closer look, figures 5 and 6 are plotted on the same graph (Figure 7). It is obvious how time shifting took place between indoor temperatures (T6) of control and CO-PCM tests. For approximately the same outdoor conditions (T4), floor surface temperature (T5) increased to $25{ }^{\circ} \mathrm{C}$ in the control test while achieving the comfort indoor temperature level, while it reached $34{ }^{\circ} \mathrm{C}$ in the PCM case, thus reflecting the capability of reaching suitable floor surface temperature while maintaining thermal comfort for a longer duration with less fluctuation. 


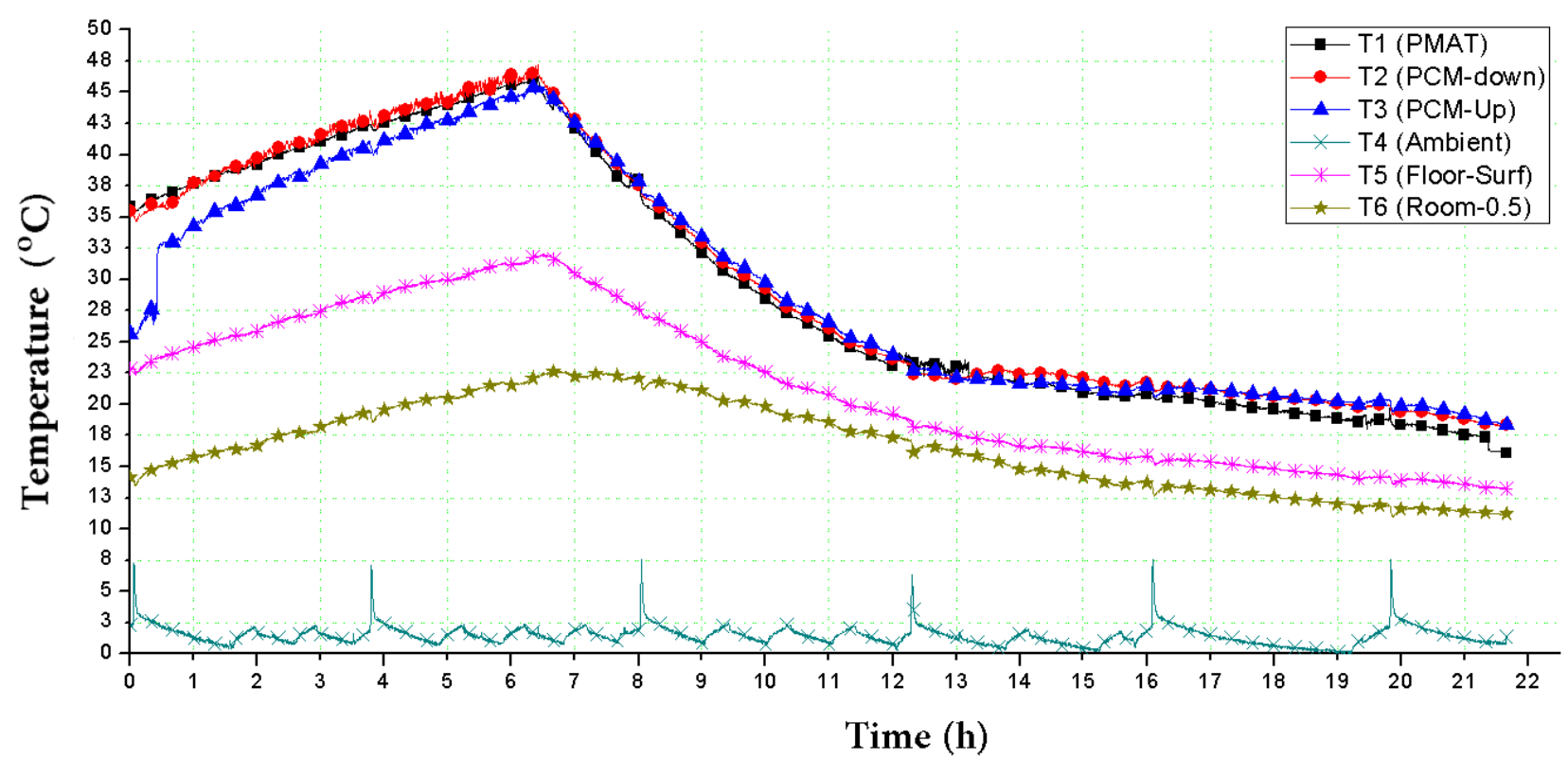

Figure 6 Variation in temperature with respect to time in the CO-PCM test

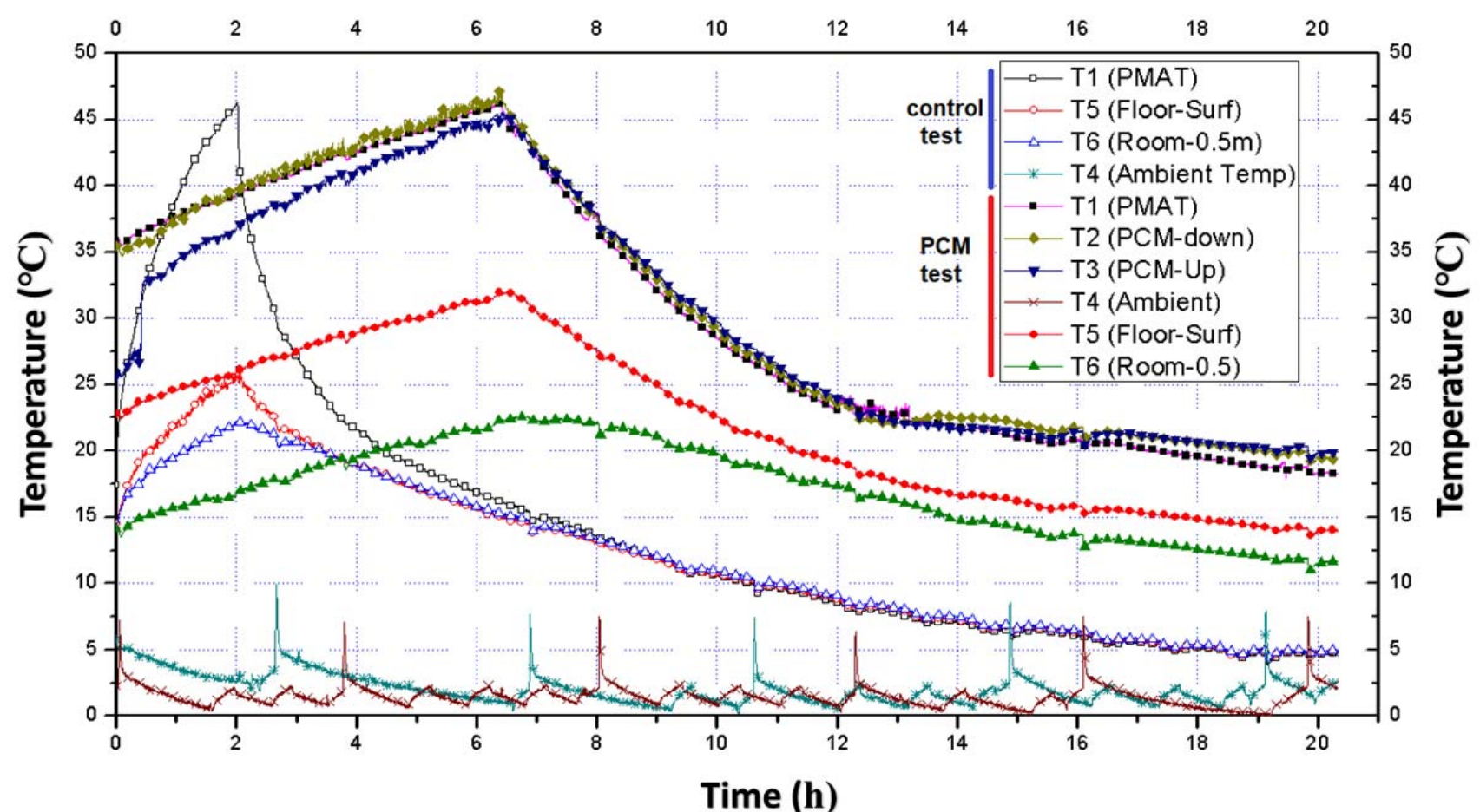

Figure 7 Variation of temperature with respect to time in both tests: (1) Control test and (2) PCM test.

A separate graph representing the comparison between the indoor and outdoor temperatures as functions of time in the case of both the control and PCM tests is presented in Figure 8 to ensure precise analysis of peak load shifting, thereby adding to the investigation that the rationale of the first law of thermodynamics is pragmatic in this study wherein energy is conserved. 


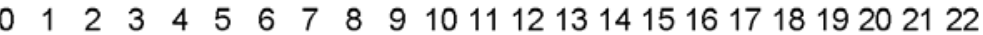

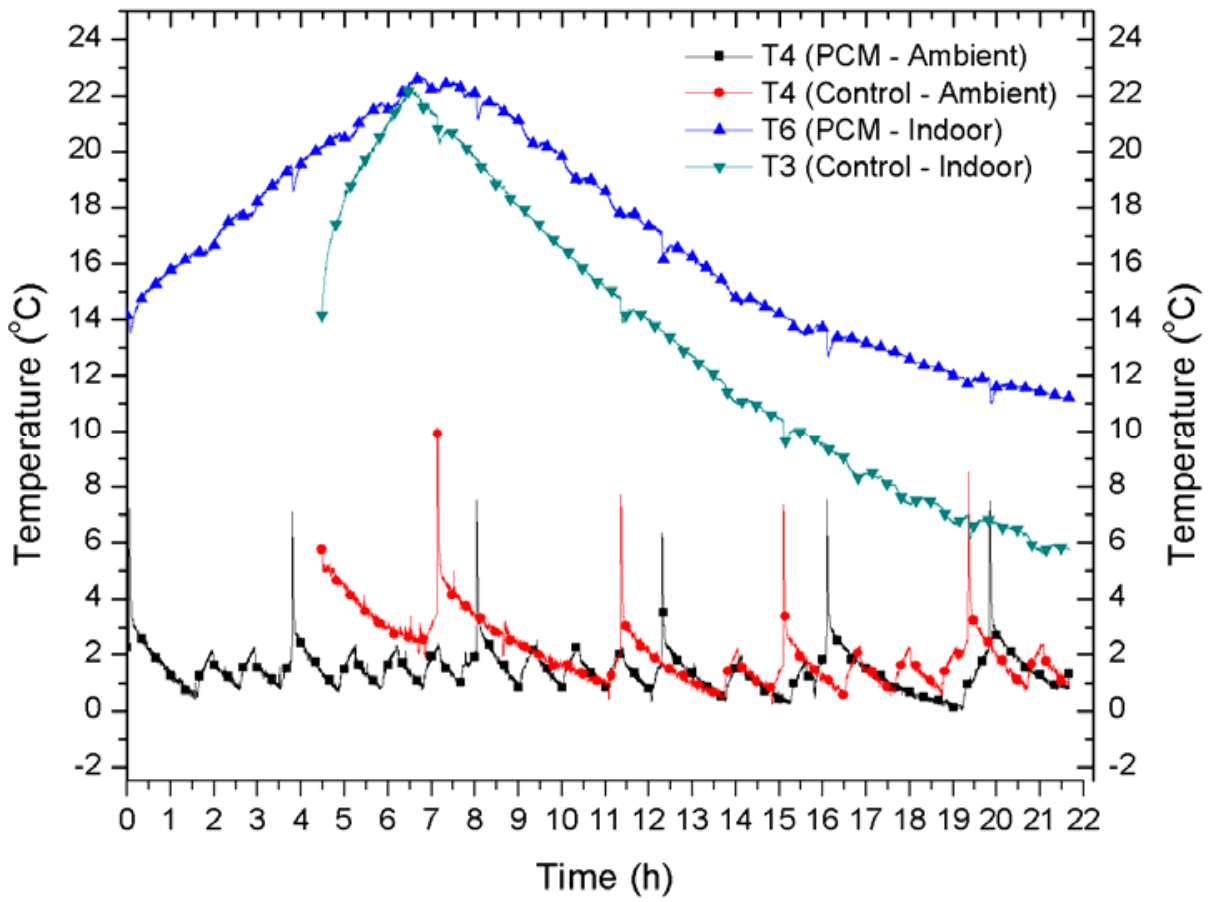

Figure 8 Variations in room and ambient temperatures with respect to time in both control and CO-PCM tests

To inspect the processes of charging and discharging of CO-PCM, the variations in the temperature of CO-PCM and room temperature as functions of time are shown in Figure 9. The graph shows that the CO-PCM entered two stages: sensible heating and latent heating. After the process of PMAT heating ended, the sensible energy of the PCM contributed to a delay in the process of cooling of the room. However, it is evident from the graph that the latent energy stored in the PCM started being utilized at a lower temperature $\left(22-23^{\circ} \mathrm{C}\right)$. This shows that the solidification temperature of the CO-PCM is lower than its melting temperature, which is a property that was inspected by Vik et al. while studying the thermal performance of a bio-PCM named "Bio-PCM Q23 M51" that had a melting point of $23{ }^{\circ} \mathrm{C}$ and solidification point of $18.5^{\circ} \mathrm{C}$ [6]. Thus, the use of PCMs with higher solidification points would shift the utilization of their latent heats into more efficient zones.

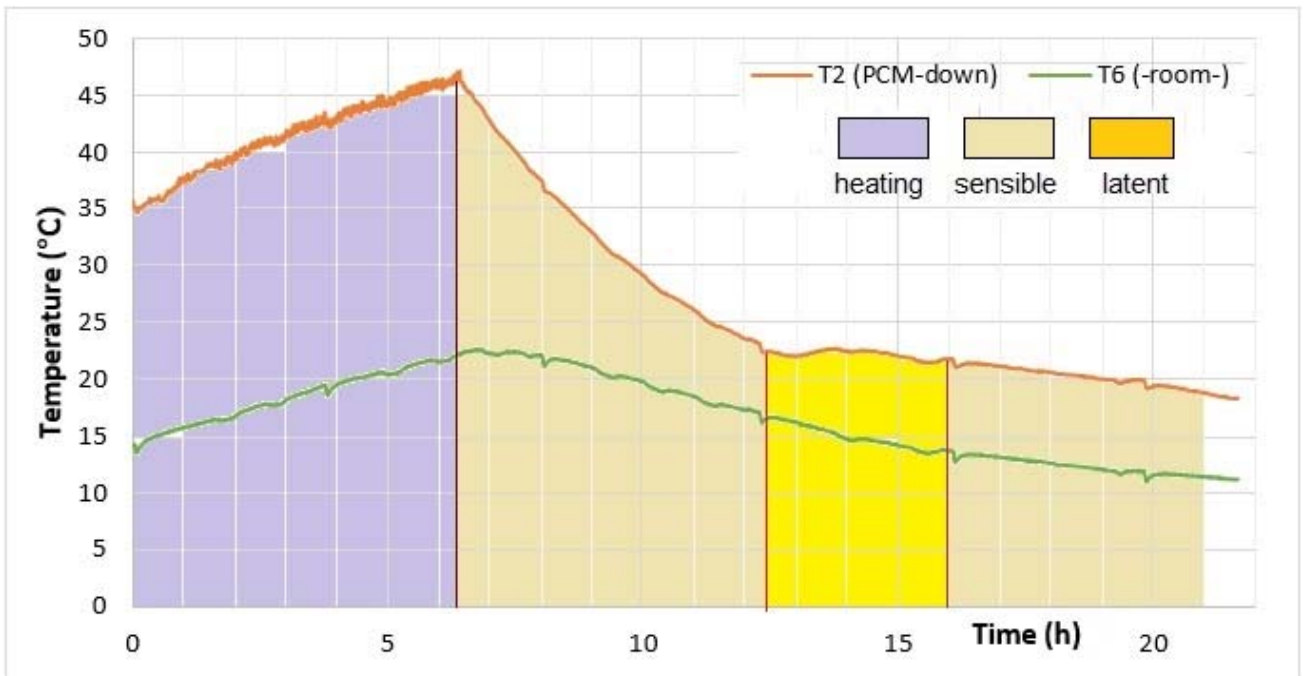

Figure 9 Variation in PCM lower surface temperature with respect to time in the CO-PCM test 
Coconut oil used in this study is indeed one of plenty of bio-PCMs available in nature, and its characteristics compared to other PCMs is of great interest. Several studies on using PCMs with underfloor heating systems were conducted by implementing bio-PCMs and other common PCMs like paraffin. For direct comparison, and to show the advantages of using Coconut oil on other PCM types in such a case, Table 4 below summarizes the thermophysical characteristics for PCMs of some similar studies. It is shown that CO-PCM has dominant properties that best suits the application of underfloor heating. Most paraffin-based PCMs are highly flammable if not adapted with fire retardant materials that alerts their thermophysical properties. Coconut oil being inflammable have a priority on paraffins. It is clear that the most advantage that CO-PCM has is its relatively high heat of fusion compared to other PCMs. The melting temperature is found to be suitable in many choices, however, the low latent heat problem arises. Some BioBased PCMs such as: Hydrogenated Palm Kernel vegetable fat seems to be promising. It is chemically and thermally stable, and of suitable melting temperature. Unfortunately, its lower storage capacity $(74.35 \mathrm{~kJ} / \mathrm{kg})$ which decreases to $41.13 \mathrm{~kJ} / \mathrm{kg}$ upon adding supporting materials makes the choice quite far. In-organic PCMs such as sodium acetate trihydrate-urea with expanded graphite have both high heat of fusion and suitable high thermal conductivity, but with high melting temperature. A study with new class of organic-based BioPCM was prepared by Muruganantham et al. [28] showed a maximum energy and cost savings of about $30 \%$, and a maximum peak load shift of about $1 \mathrm{hr}$. The study utilized BioPCM with thermophysical properties that are very close to those in the current study for CO-PCM.

Table 4 Characteristics of other PCM types compared to the PCM in the current study

\begin{tabular}{|c|c|c|c|c|c|c|}
\hline \multirow{3}{*}{ PCM type } & \multicolumn{5}{|c|}{ Characteristics } & \multirow{3}{*}{ Ref. } \\
\hline & $\begin{array}{c}\text { Heat of fusion, } \\
\mathrm{H}_{\mathrm{f}}\end{array}$ & $\begin{array}{c}\text { Melting } \\
\text { temperature, } \mathrm{T}_{\mathrm{m}}\end{array}$ & $\begin{array}{l}\text { Specific } \\
\text { Heat, } C_{p}\end{array}$ & $\begin{array}{c}\text { Conductivity, } \\
\lambda \\
\end{array}$ & Flammability & \\
\hline & $\mathrm{kJ} / \mathrm{kg}$ & ${ }^{\circ} \mathrm{C}$ & $\mathrm{kJ} / \mathrm{kg} \cdot \mathrm{K}$ & $\mathrm{W} / \mathrm{m} . \mathrm{K}$ & - & \\
\hline $\begin{array}{l}\text { Paraffin-based } \\
\text { eutectic SSPCM }\end{array}$ & 62.24 & $19-26$ & 3.26 & 0.12 & - & [29] \\
\hline Paraffin GR27 & 72 & 27 & 1.5 & 0.2 & - & [15] \\
\hline $\begin{array}{l}\text { In-organic salthydrate } \\
\text { (sodium acetate } \\
\text { trihydrate-urea } \\
+ \text { expanded graphite) }\end{array}$ & 223.1 & 47.84 & - & 2.076 & - & [30] \\
\hline Capric acid & 162 & 29.3 & 2 & $\begin{array}{l}0.36 \text { (solid) } \\
0.17 \text { (liquid) }\end{array}$ & - & [14] \\
\hline $\begin{array}{l}\text { Palm Kernel } \\
\text { vegetable fat }\end{array}$ & 74.35 & 26.53 & - & 0.2 & - & [31] \\
\hline $\begin{array}{l}\text { Organic-based } \\
\text { BioPCM }\end{array}$ & 219 & 29 & 1.97 & 0.2 & Less-flammable & [28] \\
\hline Coconut oil (CO) & 254.5 & 28 & 2.1 & $0.5[25]$ & Nonflammable & $\begin{array}{l}\text { Current } \\
\text { study }\end{array}$ \\
\hline
\end{tabular}

Finally, the essential portions of the resultant graphs, which is the variation in room temperature between $22{ }^{\circ} \mathrm{C}$ and $20^{\circ} \mathrm{C}$ during heating and cooling in both the scenarios, are replotted on a daily basis, as shown in Figure 10. As one cycle comprises heating from $20^{\circ} \mathrm{C}$ to $22^{\circ} \mathrm{C}$ and subsequent cooling to $20^{\circ} \mathrm{C}$, the graph shows that the duration of one cycle is $138 \mathrm{~min}$ in the control test and $333.25 \mathrm{~min}$ in 
the PCM test. So, the number of cycles needed for one day is 10.43 in the control test and 4.32 in the PCM test.

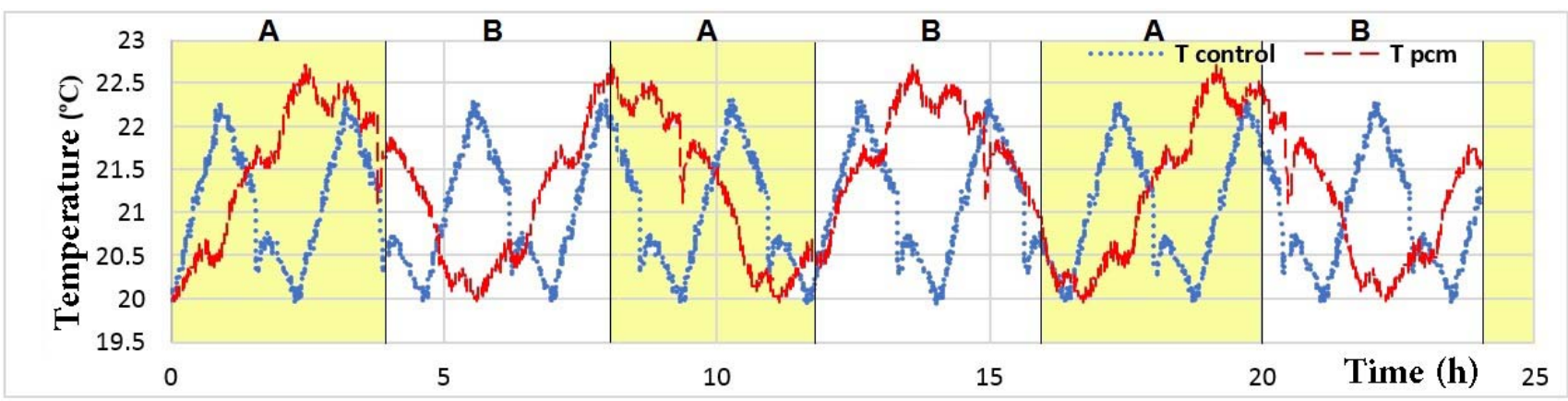

Figure 10 Heating and cooling cycle for the room between lower and upper comfort temperature bounds over 24 h, with PCM and without PCM

\section{Economic evaluations}

The use of coconut oil as a PCM in an underfloor electric heating system proved to be an effective means of energy conservation. The Lebanese government offers electricity to each district in intervals of $4 \mathrm{~h}$, and this is shown in Figure 10, wherein the shaded parts (zones A) represent the time of availability of government-supplied electricity (considered off-peak times) and the unshaded parts (zones B) represent the time of personal electricity generation (considered peak times). To compare the operational cost of the control test with that of the PCM test, it is assumed that the hours of zone A are used for heating and those of zone B are used for cooling. The graph displayed in Figure 10 is accordingly replotted in Figure 11. Table 5 shows the specifications of zones A and B.

Table 5 Specifications of Zones A and B

\begin{tabular}{cccc}
\hline Zone & $\begin{array}{c}\text { Electricity generation } \\
\text { responsibility of }\end{array}$ & Electricity cost (L.L./kWh) & $\begin{array}{c}\text { Electricity cost } \\
\text { (USD/kWh) }\end{array}$ \\
\hline \hline $\mathrm{A}$ & $\begin{array}{c}\text { Lebanese Government [32] } \\
\text { Personal electricity generator } \\
\text { B }\end{array}$ & 112 & 0.07392 \\
\hline
\end{tabular}

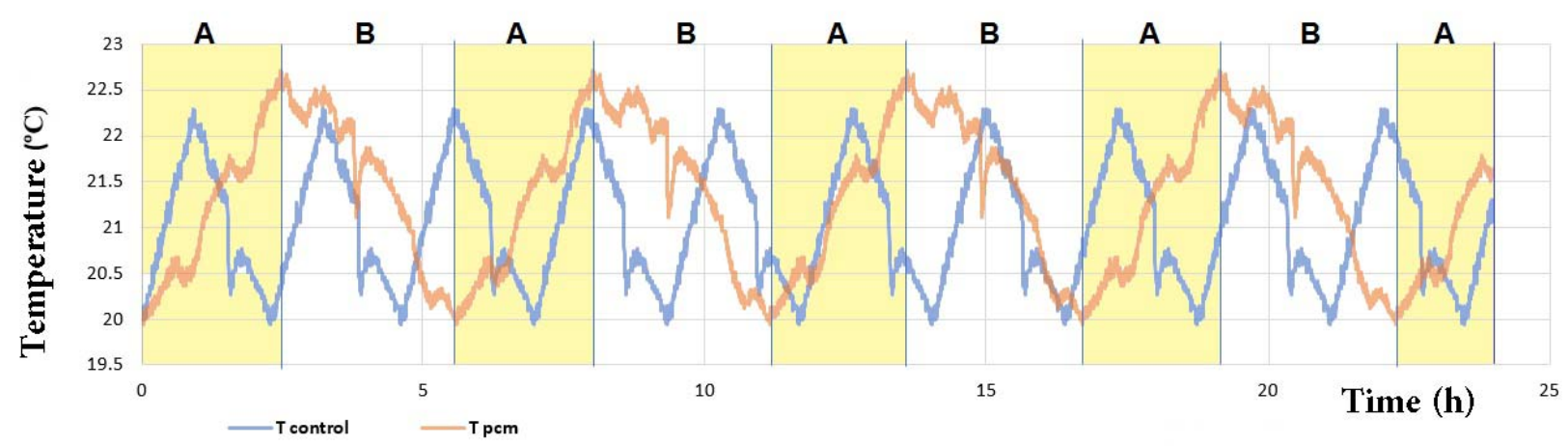

Figure 11 Heating and cooling cycles for the room distributed over time zones A and B. 
For the purpose of economic evaluation, the values pertaining to zone A in Table $\mathbf{5}$ are retrieved from the website of the Lebanese government, assuming that zone $\mathrm{A}$ is outside the night drop and evening peak periods for medium tension [28]. The electricity cost is calculated based on the time-of-use tariff policy; however, for extreme performance enhancement using PCM, the assumption was made such that the tariff policy is unique (medium tension, and outside night drop and evening peak periods).

Based on the distribution assumed, it is evident that the use of CO-PCM shifted electricity consumption from zone B to zone A by approximately 57\% when compared with the control test.

Given that the operational voltage and current during both the experiments were measured to be $220 \mathrm{~V}$ and $0.98 \mathrm{~A}$, respectively, the results show that by using CO-PCM in the prototype designed in this study, the decrease achieved in annual running costs is USD 98, which is equivalent to a reduction of $58.9 \%$ when compared with the control room with no PCM, as depicted in Table 6.

The total daily energy consumption in the PCM test was approximately $25 \%$ higher than that in the control test. This difference might be due to the thermal resistance effect caused by the air gap above the PCM and the low thermal conductivity of the PCM, resulting in greater loss through the floor and walls at the boundaries of the plate.

Table 6 Durations of heating and cooling cycles and the respective operational costs

\begin{tabular}{cccccc}
\hline Test Scenario & $\begin{array}{c}\text { Heating duration } \\
\text { zone A }(\mathrm{min})\end{array}$ & $\begin{array}{c}\text { Heating duration } \\
\text { zone B }(\mathrm{min})\end{array}$ & $\begin{array}{c}\text { Total daily energy } \\
\text { consumption } \\
(\mathrm{kWh})\end{array}$ & $\begin{array}{c}\text { Total daily } \\
\text { operational cost } \\
(\mathrm{USD})\end{array}$ & $\begin{array}{c}\text { Total annual } \\
\text { operational cost } \\
(\mathrm{USD})\end{array}$ \\
\hline \hline Control test & 243 & 330 & 2.058 & 0.4558 & 166.38 \\
CO-PCM test & 705 & 0 & 2.533 & 0.1872 & 68.34 \\
\hline
\end{tabular}

The assembled prototype parts and their respective initial costs are presented in Figure 12 below. The total initial cost is calculated and found to be USD 650. Then, with a total annual saving of USD 98, the estimated payback period for the underfloor electrical heating integrated with CO-PCM plates system is 6.63 years.

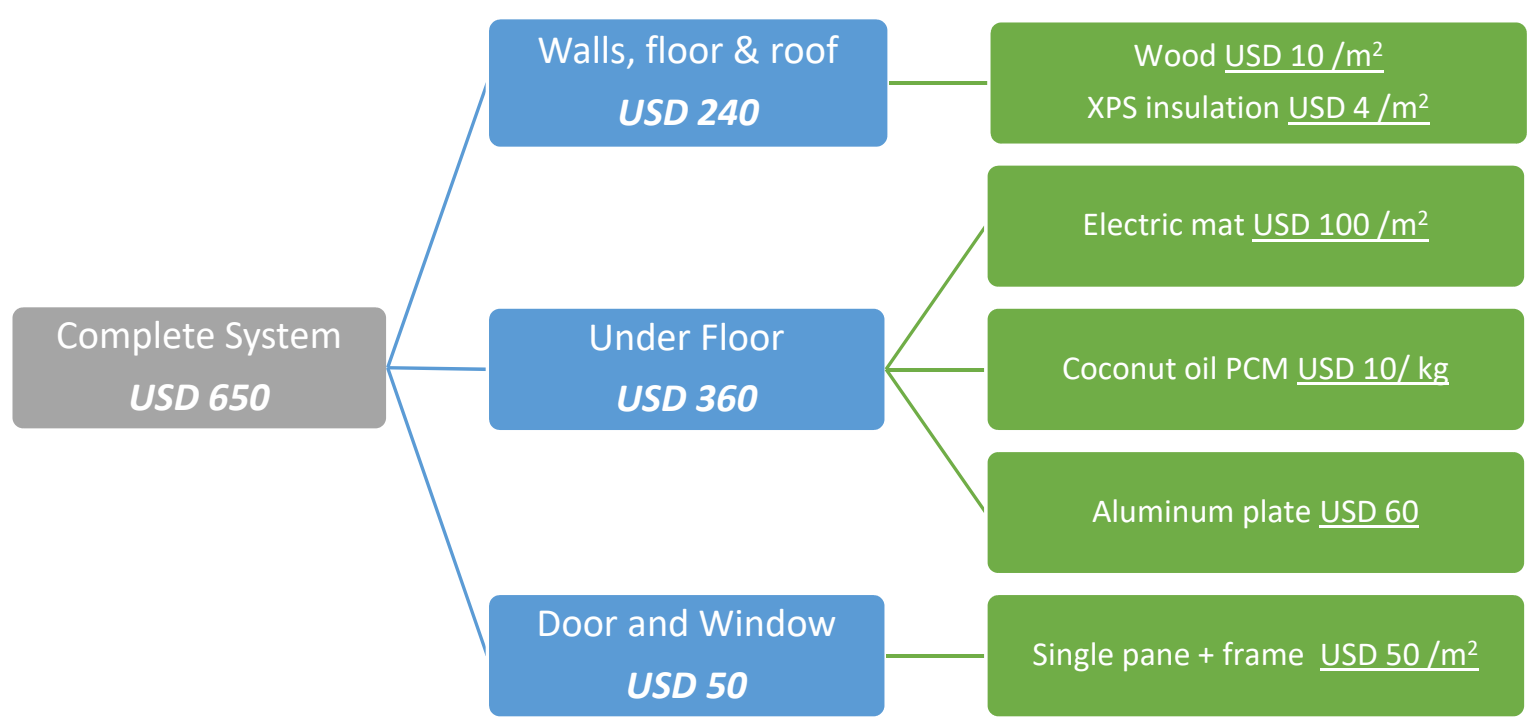

Figure 12 Total and detailed initial costs for the prototype and the system used 


\section{Conclusions}

The present work aimed to experimentally investigate and physically analyze the thermal performance of an underfloor electrical heating system integrated with coconut oil plates during winter.

The experiments were conducted on quarter-scale insulated prototypes placed inside an agricultural refrigerator that served as a thermal chamber to simulate severe winter conditions. The study compared two different cases: one with PCM plates above the electrical heater, and the other without the PCMs and plates.

It was shown that during the process of heating, i.e., the charging phase, the duration for regulation of indoor temperature from $20{ }^{\circ} \mathrm{C}$ to $22{ }^{\circ} \mathrm{C}$ was $2.08 \mathrm{~h}$ in the PCM test compared with $0.89 \mathrm{~h}$ in the absence of CO-PCM. However, the duration of cooling, i.e., the discharging phase, in the PCM test was $3.50 \mathrm{~h}$ compared with $1.41 \mathrm{~h}$ in the control test. A total of 4.32 heating-cooling cycles were required for daily temperature regulation using PCM compared with 10.40 heating-cooling cycles using the control test. This reflects the prevailing outcome, i.e., coconut oil achieved a shift in electricity consumption from peak position to off-peak position and a reduction of $58.9 \%$ in running costs when compared with the control test.

\section{References}

[1] K. Du, J. Calautit, Z. Wang, Y. Wu, and H. Liu, "A review of the applications of phase change materials in cooling, heating and power generation in different temperature ranges," Appl. Energy, vol. 220, no. March, pp. 242-273, 2018.

[2] W. Wu et al., "Experimental study on the performance of a novel solar water heating system with and without PCM," Sol. Energy, vol. 171, no. July, pp. 604-612, 2018.

[3] A. Kasaeian, L. bahrami, F. Pourfayaz, E. Khodabandeh, and W. M. Yan, "Experimental studies on the applications of PCMs and nano-PCMs in buildings: A critical review," Energy Build., vol. 154, pp. 96-112, 2017.

[4] D. Zhou, C. Y. Zhao, and Y. Tian, "Review on thermal energy storage with phase change materials (PCMs) in building applications," Appl. Energy, vol. 92, pp. 593-605, 2012.

[5] F. Souayfane, F. Fardoun, and P. H. Biwole, "Phase change materials (PCM) for cooling applications in buildings: A review," Energy Build., vol. 129, pp. 396-431, 2016.

[6] T. A. Vik, H. B. Madessa, P. Aslaksrud, E. Folkedal, and O. S. Øvrevik, "Thermal Performance of an Office Cubicle Integrated with a Bio-based PCM: Experimental Analyses," Energy Procedia, vol. 111, no. 1876, pp. 609-618, 2017.

[7] V. V. Tyagi and D. Buddhi, "PCM thermal storage in buildings: A state of art," Renew. Sustain. Energy Rev., vol. 11, no. 6, pp. 1146-1166, 2007.

[8] K. Lin, Y. Zhang, X. Xu, and H. Di, "Experimental study of under-floor electric heating system with shape-stabilized PCM plates," Energy Build., vol. 37, pp. 215-220, 2005.

[9] Z. Yinping, G. Zhou, R. Yang, and K. Lin, "Our research on shape-stabilized PCM in energyefficient buildings," Proceeding Ecostock, 10th, pp. 1-9, 2006.

[10] P. Devaux and M. M. Farid, "Benefits of PCM underfloor heating with PCM wallboards for space heating in winter," Appl. Energy, vol. 191, pp. 593-602, 2017.

[11] R. Barzin, J. J. J. Chen, B. R. Young, and M. M. Farid, "Application of PCM underfloor heating in combination with PCM wallboards for space heating using price based control system," Appl. Energy, vol. 148, pp. 39-48, 2015. 
[12] G. Zhou and J. He, "Thermal performance of a radiant floor heating system with different heat storage materials and heating pipes," Appl. Energy, vol. 138, pp. 648-660, 2015.

[13] W. Cheng, B. Xie, R. Zhang, Z. Xu, and Y. Xia, "Effect of thermal conductivities of shape stabilized PCM on under-floor heating system," Appl. Energy, vol. 144, pp. 10-18, 2015.

[14] K. Huang, G. Feng, and J. Zhang, "Experimental and numerical study on phase change material floor in solar water heating system with a new design," Sol. Energy, vol. 105, pp. 126-138, 2014.

[15] R. Ansuini, R. Larghetti, A. Giretti, and M. Lemma, "Radiant floors integrated with PCM for indoor temperature control," Energy Build., vol. 43, no. 11, pp. 3019-3026, 2011.

[16] L. Royon, L. Karim, and A. Bontemps, "Thermal energy storage and release of a new component with PCM for integration in floors for thermal management of buildings," Energy Build., vol. 63, pp. 29-35, 2013.

[17] L. Karim, F. Barbeon, P. Gegout, A. Bontemps, and L. Royon, "New phase-change material components for thermal management of the light weight envelope of buildings," Energy Build., vol. 68, no. PART B, pp. 703-706, 2014.

[18] H. Thieblemont, F. Haghighat, and A. Moreau, "Thermal Energy Storage for Building Load Management : Application to Electrically Heated Floor," Appl. Sci., vol. 194, no. 7, 2016.

[19] Y. Zhou, S. Zheng, H. Chen, and G. Zhang, "Indoor and Built Thermal performance and optimized thickness of active shape-stabilized PCM boards for side-wall cooling and underfloor heating system," Indoor Built Environ., vol. 25, no. 8, pp. 1279-1295, 2016.

[20] S. Lu, H. Tong, and B. Pang, "Study on the coupling heating system of floor radiation and sunspace based on energy storage technology," Energy Build., vol. 159, pp. 441-453, 2018.

[21] M. T. Plytaria, C. Tzivanidis, E. Bellos, and K. A. Antonopoulos, "Energetic investigation of solar assisted heat pump under fl oor heating systems with and without phase change materials," Energy Convers. Manag., vol. 173, no. August, pp. 626-639, 2018.

[22] W. A. Putri, Z. Fahmi, I. M. Sutjahja, D. Kurnia, and S. Wonorahardjo, "Thermophysical parameters of coconut oil and its potential application as the thermal energy storage system in Indonesia," J. Phys. Conf. Ser., vol. 739, no. 1, 2016.

[23] T. Bergman, A. Lavine, F. Incropera, and D. Dewitt, Fundamentals of Heat and Mass Transfer, 7th editio. USA: Jhon Wiley and sons, 2011.

[24] S. Wonorahardjo, I. M. Sutjahja, D. Kurnia, Z. Fahmi, and W. A. Putri, "Potential of Thermal Energy Storage Using Coconut Oil for Air Temperature Control," Buildings, vol. 2, 2018.

[25] P. V. Krishna, R. R. Srikant, and D. N. Rao, "Experimental investigation on the performance of nanoboric acid suspensions in SAE-40 and coconut oil during turning of AISI 1040 steel," Int. J. Mach. Tools Manuf., vol. 50, no. 10, pp. 911-916, 2010.

[26] D. Kumar, G. Kumar, and C. P. Singh, "Ultrasonics Sonochemistry Fast, easy ethanolysis of coconut oil for biodiesel production assisted by ultrasonication," Ultrason. - Sonochemistry, vol. 17, no. 3, pp. 555-559, 2010.

[27] F. McQuiston, J. Parker, and J. Spitler, Heating, Ventilating and Air Conditioning Analysis and Design, 6th editio. John Wiley \& Sons, Inc., 2005.

[28] P. Phelan, K. Muruganantham, P. Horwath, D. Ludlam, and T. McDonald, "Experimental Investigation of a Bio-Based Phase Change Material to Improve Building Energy Performance," Proc. 4th Int. Conf. Energy Sustain., 2010.

[29] J. Kosny, E. Kossecka, A. Brzezinski, A. Tleoubaev, and D. Yarbrough, "Dynamic thermal performance analysis of fiber insulations containing bio-based phase change materials ( PCMs )," Energy Build., vol. 52, pp. 122-131, 2012.

[30] W. Fu et al., "Thermal properties and thermal conductivity enhancement of composite phase change material using sodium acetate trihydrate-urea/expanded graphite for radiant floor heating system," Appl. Therm. Eng., vol. 138, no. April, pp. 618-626, 2018.

[31] L. Boussaba, S. Makhlouf, A. Foufa, G. Lefebvre, and L. Royon, "The Palm Kernel Vegetable 
Fat: a Low-cost Bio- based Phase Change Material for Thermal Energy Storage in Buildings," J. Build. Eng., 2018.

[32] Ministry of Finance, Lebanese Government, 2016. [Online]. Available: http://www.finance.gov.lb/.

[33] Anwar Al Kadri, Municipality of Al Rafeed Village, West Bekaa, Lebanon. 